\title{
New Distribution Record of the Malabar Tree Toad, Pedostibes tuberculosus Gunther 1875 (Amphibia: Anura: Bufonidae)
}

\author{
Sandeep Sreedharan ${ }^{1}$, Joelin Joseph ${ }^{1}$, Sanil George ${ }^{2}$, and Mano Mohan Antony ${ }^{1}$ \\ ${ }^{1}$ PG and Research Department of Zoology, University College and Research Centre, University of Kerala, Thiruvananthapuram, Kerala, India \\ ${ }^{2}$ Rajiv Gandhi Centre for Biotechnology, Thiruvananthapuram, Kerala, India (sgeorge@rgcb.res.in)
}

$\mathrm{T}$ The Malabar Tree Toad (Pedostibes tuberculosus) is endemic to the Western Ghats of India and is listed as endangered by the IUCN (Biju et al. 2004). The original description of the species was performed by Gunther (1875) from the southern part (Malabar) of Kerala, India. After a century, the species was rediscovered by Bhattacharya in 1980 from Silent Valley National Park, Kerala, India (Pillai 1986). The species subsequently was recorded from different parts of the Western Ghats (Inger et al. 1984; Biju 2001; Gururaja and Ramachandra 2006; Sayyed and Nale 2017). The present study reports a new distribution record of the Malabar Tree Toad from the Peppara Wildlife Sanctuary $\left(8^{\circ} 36^{\prime} 31.4^{\prime \prime N} 77^{\circ} 09^{\prime} 38.5^{\prime \prime E}\right)$ of the southern Western Ghats, India. Additionally, the details of morphological and morphometric characteristic features of the species, and phylogeny are presented.

We collected toads from moist evergreen forests of the Peppara Wildlife Sanctuary (Fig. 1) at 1800-2030 h from March to June 2019 by locating calling males or through opportunistic encounters. We photographed live individuals (Fig. 2) at sites of capture and collected toe-clips after proper antibiotic treatment. The latter were preserved in absolute ethanol for DNA isolation.

The morphological characters, measurements, and associated terminology followed Biju et al. (2014). Measurements were taken by using digital slide-callipers. Total genomic DNA was isolated from toe clips using a DNeasy Blood and Tissue Kit (Qiagen, New Delhi, India). A partial fragment of mitochondrial 16S ribosomal RNA (16S) was amplified via polymerase chain reaction using a universal primer (Palumbi et al. 1991). The PCR amplification was performed with a thermal cycler (Eppendorf) in a total volume of $10 \mu \mathrm{l}$, containing $2 \mu \mathrm{l}$ of $5 \mathrm{X}$ PCR buffer, $0.2 \mu \mathrm{l}$ of dNTP $(2 \mathrm{mM})$, $0.5 \mu \mathrm{l}$ of each primer $(10 \mathrm{mM}), 0.2 \mu \mathrm{l}$ of Phire Taq DNA polymerase (Applied Biosystems, Foster City, California), 5.5 $\mu \mathrm{L}$ of $\mathrm{ddH}_{2} \mathrm{O}$ and $1-3 \mu \mathrm{l}$ of template DNA (10-20 ng). The cycling conditions were as follows: $95^{\circ} \mathrm{C}$ for $5 \mathrm{~min}$, followed by 40 cycles of $95^{\circ} \mathrm{C}$ for $30 \mathrm{~s}, 55^{\circ} \mathrm{C}$ for $40 \mathrm{~s}, 72^{\circ} \mathrm{C}$ for 90 $s$ followed by a final extension step at $72{ }^{\circ} \mathrm{C}$ for $5 \mathrm{~min}$. We used a negative control for each round of PCR to check for contamination. PCR products were purified by using ExoSap IT (USB Corporation, Cleveland, Ohio) and sequenced in an ABI 3730 capillary sequencer using Big Dye Terminator V.3.1 Cycle sequencing kit (Applied Biosystems).

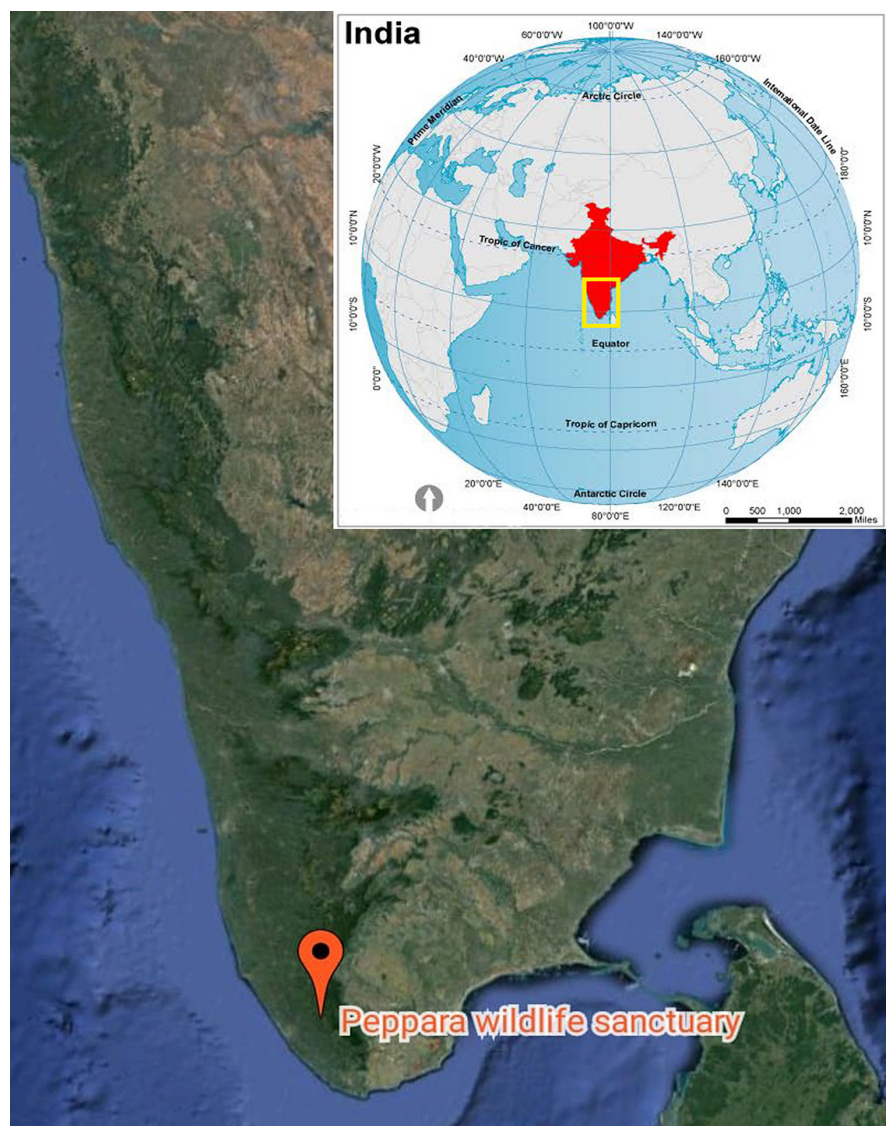

Fig. 1. Location of the Peppara Wildlife Sanctuary in the southern Western Ghats of India: Site of a new distributional record of the Malabar Toad (Pedostibes tuberculosis). 

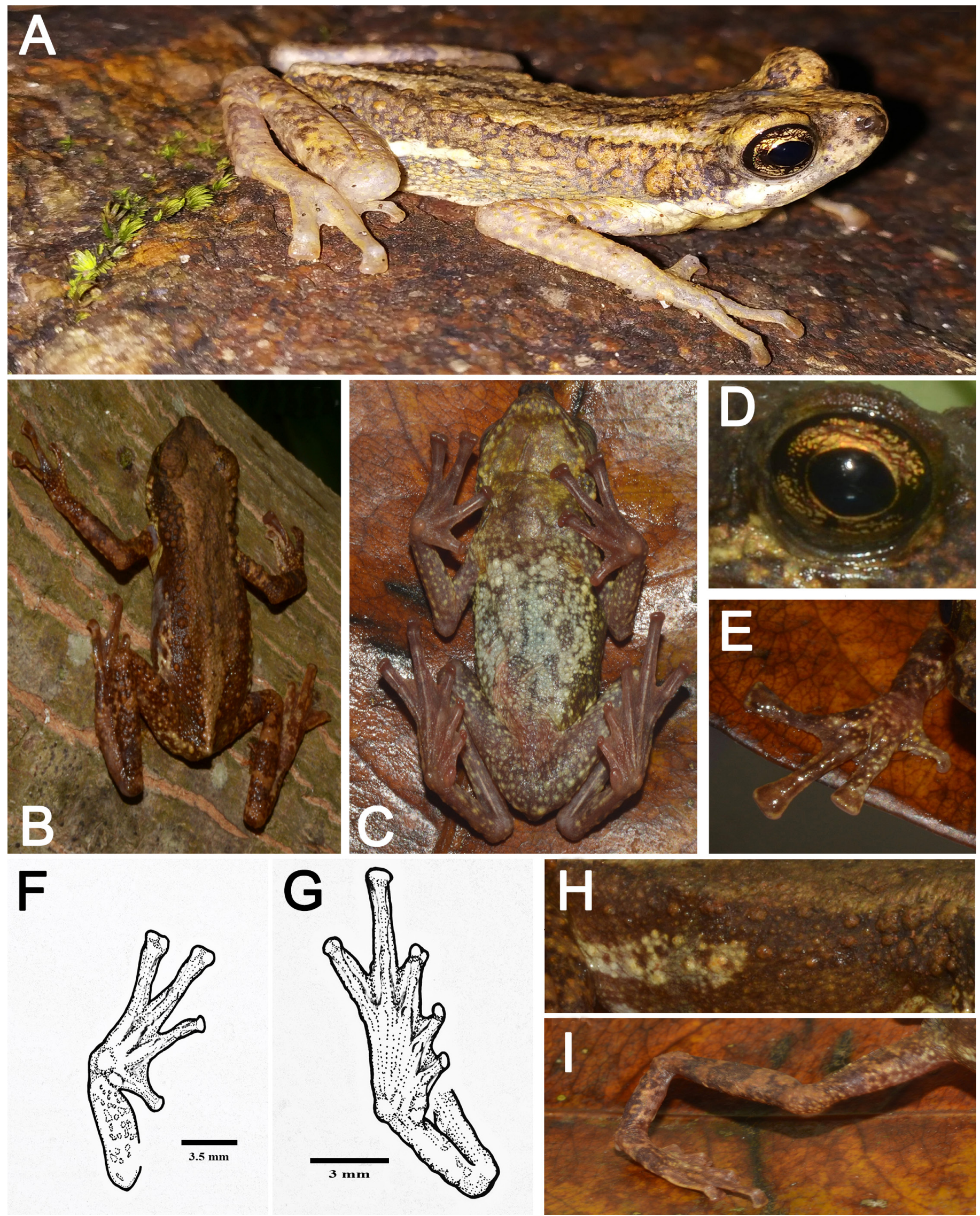

Fig. 2. Malabar Toads (Pedostibes tuberculosis) in natural habitat (A), dorsum (B), venter (C), eye (D), forelimb (E), dorsal view of the forelimb (F), dorsal view of the hindlimb $(\mathrm{G})$, skin with tubercles $(\mathrm{H})$, and hindlimb (I). Photographs by Sandeep Sreedharan. 
Sequences were aligned using Bioedit (Hall 1999). Taxonomy was confirmed by the sequence similarity using BLAST (https://blast.ncbi.nlm.nih.gov/Blast.cgi). The sequences that showed close similarity to the $16 \mathrm{~S}$ rRNA sequences of the species are extracted from NCBI, and a phylogenetic tree was constructed using MEGA 5.0 (Tamura et al. 2011). The sequence was deposited in the GenBank under accession number MN227238.

The dorsum is warty and dark brownish-gray with yellowish-brown patches (Fig. 2b). Sides have 17-20 moderately sized $(0.70-1.38 \mathrm{~mm})$ tubercles of tawny brown (Fig. 2h). Tubercles are darker at the base and lighter toward the tip. The venter has whitish patches on the abdomen and thorax (Fig. 2c). The ventral surfaces of the jaws and limbs are yellowish-brown. The tympanum is distinct. The pupil is rounded and black. The iris is golden yellow interspersed with small black lines (Fig. 2d). The snout is protruding and obtusely pointed, but the tip is not sharp.

Dorsoterminal groves of the third finger and fourth toe are rounded distally (Fig. 2e). Both finger and toe tip are truncated discs (Figs. 2e and 2i). Parotid glands are present but not prominent. Eyes protrude slightly dorsally. In males, a single round nuptial pad is present on the base of the first finger. The single vocal sac is distinct while calling. The posterior part of the flank of females is broader than that of males. Single subarticular tubercles are well developed and oval (Fig. 2g). A prepollex is absent but palmar tubercles are present. Webbing extends to the first subarticular tubercle of the fourth toe on either side or just beyond the second subarticular tubercle on either side.

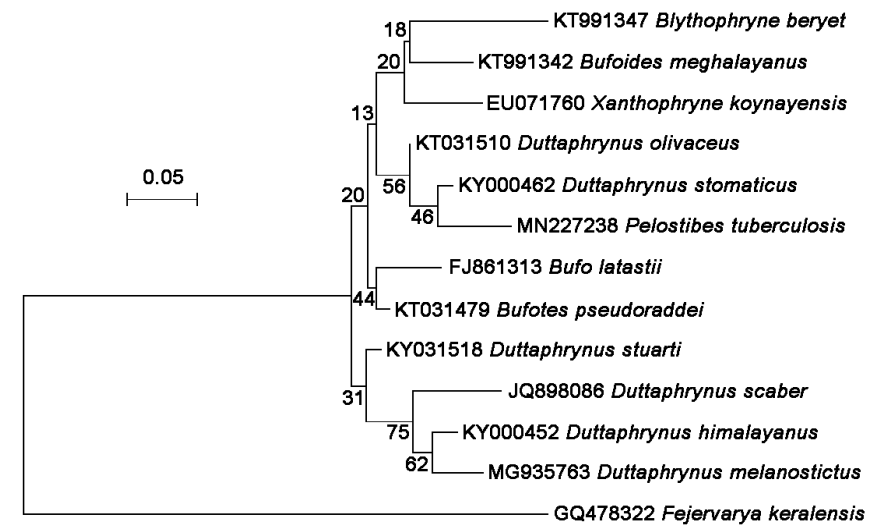

Fig. 3. Maximum-likelihood tree (Tamura-Nei Model) using 16S sequences of Indian toads.
Adult males (SLV $32.82 \pm 0.18 \mathrm{~mm}$ ) are smaller than females (SLV $36.24 \pm 0.30 \mathrm{~mm}$ ). Head width in both sexes is wider than head length. Nostrils are closer to the tip of the snout than the eye. In both sexes, interorbital space is flat and wider than eye length. The tibia is longer than the thigh. The order of relative lengths of fingers is $3 \mathrm{FL}>4 \mathrm{FL}>2 \mathrm{FL}>1 \mathrm{FL}$ and that of toes is $4 \mathrm{TL}>5 \mathrm{TL}>3 \mathrm{TL}>2 \mathrm{TL}>1 \mathrm{TL}$. Inner metatarsal tubercle length of both males and females are the same.

Relationships of Pedostibes tuberculosus with other Indian toads are illustrated in Fig. 3. Chan et al. (2016) demonstrated that Pedostibes of India differed substantially from Southeast Asian species assigned to the genus.

\section{Acknowledgements}

The authors are grateful to RGCB, Thiruvananthapuram, Kerala, and the Kerala Forest Department for providing facilities for this study. SS and JJ thank the Government of Kerala for the ASPIRE Fellowship. JJ also thanks CSIR for a Junior Research Fellowship.

\section{Literature Cited}

Biju, S.D. 2001. A Synopsis to the Frog Fauna of the Western Ghats, India. Occasional Publication: The Indian Society for Conservation Biology (ISCB), Tropical Botanic Garden and Research Institute, Thiruvananthapuram, India.

Biju, S.D., S. Dutta, R. Inger and V.A. Gour-Broome. 2004. Pedostibes tuberculosus. The IUCN Red List of Threatened Species 2004: e.T16470A5918772.

Biju, S.D., S. Garg, K.V. Gururaja, Y. Shouche, and S.A. Walujkar. 2014. DNA barcoding reveals unprecedented diversity in dancing frogs of India (Micrixalidae, Micrixalus): A taxonomic revision with description of 14 new species. Ceylon Journal of Science (Biological Sciences) 43(1): 37-123.

Chan, K.O., L.L. Grismer, A. Zachariah, R.M. Brown, and R.K. Abraham. 2016. Polyphyly of Asian tree toads, genus Pedostibes Günther, 1876 (Anura: Bufonidae), and the description of a new genus from Southeast Asia. PloS One 11.1: e0145903.

Günther, A. 1875. Third report on collections of Indian reptiles obtained by the British Museum. Proceedings of the Zoological Society of London 1875: 567-577.

Gururaja, K.V. and T.V. Ramachandra. 2006. Pedostibes tuberculosus (Malabar Tree Toad). Advertisement call and distribution. Herpetological Review 37: 75-76.

Hall T.A. 1999. BioEdit: A user-friendly biological sequence alignment editor and analysis program for Windows 95/98/NT. Nucleic Acids Symposium Series 41: 95-98.

Inger, R.F., H.B. Shaffer, M. Koshy and R. Bakde. 1984. A report on a collection of amphibians and reptiles from Ponmudi, Kerala, South India. Journal of the Bombay Natural History Society 81: 406-427.

Palumbi, S.R., A. Martin, S. Romano, W.O. McMillan, L. Stice, and G. Grabowski. 1991. The Simple Fool's Guide to PCR. Department of Zoology, University of Hawaii, Honolulu, Hawaii.

Pillai, R.S. 1986. Amphibian fauna of Silent Valley, Kerala, S. India. Records of the Zoological Survey of India 84: 229-242.

Sayyed, A. and A. Nale 2017. New distribution record and intergeneric amplexus in the Malabar Tree Toad, Pedostibes tuberculosus Günther 1875 (Amphibia: Anura: Bufonidae). Reptiles \& Amphibians 24: 193-196.

Tamura, K., D. Peterson, N. Peterson, G. Stecher, M. Nei, and S. Kumar. 2011. MEGA5: Molecular evolutionary genetics analysis using maximum likelihood, evolutionary distance, and maximum parsimony methods. Molecular Biology and Evolution 28: 2731-2739. 